\title{
Atrazine and metolachlor contamination in surface and ground water in the Zomba/Bvumbwe region in Malawi
}

\author{
Deliwe Dinah Lakudzala \\ Department of Physics and Bio-Chemical Sciences, Malawi Polytechnic, \\ P/Bag 303, Chichiri, Blantyre 3, Malawi \\ E-mail address: dlakudzala@poly.ac.mw
}

\begin{abstract}
A snapshot survey was conducted to assess ground and surface water contamination by atrazine and metolachlor in the Zomba/Bvumbwe region. Ground and surface water samples were collected and their atrazine and metolachlor were extracted using ethyl acetate. The extracts were cleaned up using florisil, concentrated on a rotary evaporator and detected using thin layer chromatography. No herbicide residue was detected in the groundwater samples. In surface water samples atrazine was detected in $38 \%$ and metolachlor was detected in $15 \%$ of the samples. The concentrations of the herbicides were at their highest soon after the first run off event after herbicide application. The concentrations, however were generally below the World Health Organization's (WHO's) recommended maximum guideline values $(2 \mu \mathrm{g} / \mathrm{ml}$ atrazine and $10 \mu \mathrm{g} / \mathrm{ml})$ metolachlor. Following the first run off event concentrations of herbicides steadily decreased with time, decreasing to zero within eight weeks of herbicide application at $37 \%$ of the water sampling points that had herbicide contamination. Light soaking rains, higher clay content, flat land, longer distance between agricultural land and surface water body (filtering area), lower herbicide application rates and herbicide incorporation seemed to reduce herbicide export to surface water. Based on the study it is recommended that regular monitoring of pesticides in water should be done and that quantification of the pesticides should be done more accurately using a gas or liquid chromatograph with appropriate detectors. It is also recommended to follow good land husbandry practices to reduce export of pesticides to surface water bodies.
\end{abstract}

\section{Keywords:}

Herbicides; atrazine; metolachlor; water; Zomba/Bvumbwe region 


\section{INTRODUCTION}

\section{1. Background}

Pesticides have improved the quality of life by controlling insects that transmit diseases or damage property and increasing crop and animal production. Although there are many benefits from the use of pesticides, the misuse of pesticides can cause both environmental pollution and economic losses. There is concern that pesticide misuse may contaminate agricultural products as well as surface and groundwater and have adverse impacts on public health and wildlife. To protect human health and the environment, the Stockholm Convention (Stockholm Convention, 2001), a global treaty on persistent organic pollutants, was adopted in 2001. The Stockholm Convention bans or severely restricts the use of persistent organic pollutants (chemicals that remain intact in the environment for long periods of time, are widely distributed geographically, accumulate in fatty tissue of living organisms and are toxic to humans and wildlife). The persistent pesticides are DDT, aldrin, dieldrin, endrin, chlordane, heptachlor, hexachlorobenzene, mirex and toxaphene. Less persistent pesticides are currently being used although these also contaminate the environment. They have been found in water and air at levels that give cause for concern in spite of the relatively rapid degradation rates quoted for the compounds (Chapman, 1992; McConnell, 2005). For example, very high levels of atrazine (2-chloro-4-(ethyl amino)-6-isopropylamine-1,3,5triazine) and metolachlor (2-chloro-N-(2-ethyl-6-methyl phenyl-N-(2-methoxy-1-methyl ethyl) acetamide) have been detected in surface and ground waters in temperate regions (US EPA, 2002; EXTOXNET, 2000a and b; Rebich et al, 2004; Savoca et al, 2000; WHO, 1996; EWG, 2004) and in tropical regions (Lanchote et al, 2000; Laabs et al, 2002 and Li et al, 2001; Du Preez et al, 2005)). In the United States of America, from 2000 to 2003, atrazine and metolachlor in air ranged from 0 to 62 and 0 to $78 \mathrm{ng} / \mathrm{m} 3$, respectively; in rain they ranged from 0 to 37 and 0 to $55 \mathrm{ng} / \mathrm{m} 3$, respectively, with maximum concentration peaks occurring during herbicide application periods (USGS, 2001)

Atrazine and metolachlor are harmful. Atrazine has been reported to have long-term reproductive and endocrine-disrupting effects. Reports have indicated that atrazine disrupts frog development and also causes a variety of adverse effects in fish, including reduced reproduction, kidney damage, disruption of normal behaviour and decreased ability to withstand warm temperatures (Hayes et al, 2002; USGS, 2001). Atrazine is also reported to be probably a human carcinogen (Van Leeuwen et al, 1999). N-nitrosamines, which may be formed in soils that have been treated with atrazine, have mutagenic and carcinogenic properties (Ayanaba et al, 1973). Atrazine is banned in some countries (including Angola) and restricted in South Africa (Zeljezic et al, 2006). Metolachlor has the potential to cause liver damage and irritation of skin, eyes and mucous membranes from a lifetime exposure at levels above the MCL. Signs of human intoxication from metolachlor exposure include abdominal cramps, anaemia, and shortness of breath, dark urine, convulsions, diarrhoea, jaundice, weakness, nausea, sweating and dizziness (EXTOXNET, 1996). However, metolachlor is not carcinogenic or mutagenic.

Individuals may be exposed to atrazine or metolachlor by drinking water from wells or rivers which are contaminated with the herbicides or swimming in herbicide contaminated waters. Farm workers, chemical sprayers and people who work in factories that make the herbicides may also be exposed. Individuals can also be exposed to the herbicides by digging in soil or dirt that contains the herbicide residues. Exposure through food or inhalation is very 
rare as the herbicide concentrations are low in air and the herbicides are rarely found in food; if found it is only at very low levels (US EPA, 2002). WHO (1990) estimated that 5-10\% of the agricultural population in developing countries are likely to have significant exposure to pesticides leading to pesticide poisoning. According to Saka (1999) the situation could arise due to lack of knowledge on toxicity and harmfulness of pesticides and inadequate knowledge on correct application procedures (to protect oneself and the environment) and dosages that are common in these areas [1-37].

\section{2. Utilization of pesticides in Malawi}

In Malawi, rapid agricultural development has led to an increased use of pesticides. At least 2000 metric tons of pesticides are used annually, 70\% of which are used for agriculture.

The term pesticides in this paper includes insecticides, herbicides, fungicides, fumigants, and Rodenticides, While insecticides are mostly used in field crops, fumigants are mostly used in the tobacco industries and herbicides are mostly used in the sugarcane plantations, coffee, cotton and tobacco fields. The mostly used pesticides are insecticides, followed by herbicides. Quantities of insecticides are large but fluctuate with time, depending on pest or disease outbreaks. The use of herbicides has steadily increased with time from 1998. The increase in use of herbicide is in line with what is happening on the global level.

According to Kearney and Kaufman (1975) the production and use of insecticides have remained fairly constant over the last several years but there has been a dramatic increase in the use of herbicides in plant production programs. As the world's demand for food increases, as labour becomes scarce and expensive and as no till or minimum tillage soil conservation practices are implemented, the most rapid rates of expansion in pesticide production will be in the field of herbicides. Hand hoeing is the most common method used to control weeds by small scale farmers in Malawi and this is labour intensive. The impacts of both rural-urban migration and HIV/AIDS are making it increasingly difficult for many families to successfully weed their crops using this method. The Sasakawa Global 2000 Malawi (which started in 1998 and completed in 2006) encouraged small scale farmers to use herbicides as a way of promoting conservation tillage and overcoming labour scarcity during high labour demand periods.

\section{3. Problem statement and objectives of the study}

There are indications that pesticide contamination in water exists in Malawi. Government water quality tests had identified dangerously high levels of aldrin and dieldrin in Lilongwe River (MEREP, 1995). The aldrin and dieldrin were believed to have come from termite control activities. Kamperewera et al (2000) found high levels of aldrin, lindane and some DDT isomers in sediments in Mtemankhokwe stream in Mangochi district. However concentrations of these compounds in the water from Lake Malawi were relatively low (Karrlson et al, 2000). Banda (2004) found DDT, aldrin and hexachlorocyclohexane isomers $(\alpha-\mathrm{HCH}, \delta-\mathrm{HCH}$ and $\gamma-\mathrm{HCH})$ in water in Lunyangwa river basin, and in most cases the pesticides exceeded $100 \mu \mathrm{g} / \mathrm{l}$. He also found that $\alpha-\mathrm{HCH}, \gamma-\mathrm{HCH}$ and aldrin were most prevalent in sediments than in the water.

However, no studies have been done to assess herbicide levels in soils and waters of Malawi. This study, therefore, concerned the extent and trends of atrazine and metolachlor contamination in some surface and ground waters in Zomba/Bvumbwe region. Herbicides atrazine and metolachlor were chosen firstly because studies conducted in the USA, South Africa and elsewhere on various pesticides have shown that the two are the most common 
pesticide contaminants in ground and surface waters (US EPA, 2002; EXTOXNET, 2000a and b; Rebich et al, 2004; Savoca et al, 2000; WHO, 1996; EWG, 2004; Du Preez et al, 2005) and secondly because of their use in agricultural practices in Malawi. Atrazine is widely used by smallholder farmers on maize fields (SG 2000 Malawi, 2006 ) and in sugarcane estates whilst metolachlor is widely used on tobacco, cotton and coffee estates.

\section{MATERIALS AND METHODS}

\section{1. Apparatus and Chemicals}

Analar grade ethyl acetate, petroleum ether, diethyl ether, sodium chloride, sodium sulphate, silver nitrate, acetone, concentrated ammonia, florisil, methanol and reference standards for atrazine $(0.1 \mathrm{~g}$ in solid form) and metolachlor $(0.1 \mathrm{~g}$ in liquid from) were used in the study. The $0.10 \mathrm{~g}$ of atrazine and metolachlor were each dissolved in $250 \mathrm{ml}$ methanol in a beaker, quantitatively transferred to a 1 litre volumetric flask and diluted to the mark with methanol to prepare $100 \mathrm{mg} / \mathrm{l}$ atrazine and metolachlor stock standard solutions which were stored in a deep freezer $\left(\right.$ at $-4{ }^{\circ} \mathrm{C}$ ) pending use. When need arose, the stock standard solutions were removed from the freezer, allowed to equilibrate to room temperature, used to prepare $2 \mu \mathrm{g} / 1$ atrazine and $10 \mu \mathrm{g} / 1$ metolachlor standard working solutions and returned to the deep freezer. The working standard solutions were kept refrigerated $\left(+4^{\circ} \mathrm{C}\right)$, until use.

Apparatus included rotary evaporator, chromatographic development chamber, UV torch, alumina chromatographic plates, glass wool and general laboratory glassware. Clean glassware was rinsed with acetone followed petroleum ether to remove traces of herbicides. Syringes were rinsed with ethyl acetate (Zweig and Sherma, 1972).

\section{2. Water Samples}

All 1-litre glass sampling bottles were thoroughly cleaned and rinsed with de-ionized water as well as ethyl acetate before use to prevent contamination. Each bottle was filled with water sample to overflowing and capped, leaving no air space and ensuring that large non homogeneous pieces of detritus, such as leaves, were excluded. The water sample bottles were sealed, labeled and placed in a cooler box with ice and transported quickly to the laboratory. The water samples were analyzed within forty eight hours of collection or kept frozen until analysis time. The 1-litre water samples were collected from the surface $(0-5 \mathrm{~cm}$ deep) within $5 \mathrm{~cm}$ from the river bank. Earlier studies had shown that this is the region with highest contamination levels of herbicides (Lakudzala, 2009).

\section{2. 1. Extent of herbicide contamination survey}

Five ground and sixty-five surface water samples were collected randomly, after the first run-off events, from some rivers (including Mponda and Chipanje rivers in Table 1) in the Zomba/Bvumbwe region. The ground water samples were collected from wells in farm areas where atrazine and metolachlor were applied. Surface water samples were collected from rivers near farm areas where atrazine and metolachlor were applied. 


\section{2. 2. Trend of herbicide contamination survey}

To assess temporal variation in water contamination, water samples were collected systematically at selected sampling points (Table 1) and times (ranging from twicemonthly during- to once a month after- herbicide use period).

Table 1. Water sampling points for atrazine and metolachlor.

\begin{tabular}{|c|c|c|c|c|c|}
\hline \multirow{2}{*}{$\begin{array}{c}\text { PROPERTIES } \\
\text { OF LAND }\end{array}$} & \multicolumn{5}{|c|}{ SAMPLING POINT } \\
\hline & STREAM 1 & STREAM 2 & STREAM 3 & STREAM 4 & STREAM 5 \\
\hline Location & $\begin{array}{l}\text { Drain, } \\
\text { Bvumbwe }\end{array}$ & $\begin{array}{l}\text { Drain, } \\
\text { Bvumbwe }\end{array}$ & $\begin{array}{l}\text { Mponda river } \\
\text { (behind } \\
\text { Chancellor } \\
\text { College's } \\
\text { maintenance } \\
\text { building) }\end{array}$ & $\begin{array}{l}\text { Drain in a } \\
\text { tobacco } \\
\text { field, } \\
\text { Makoka }\end{array}$ & $\begin{array}{c}\text { Chipanje } \\
\text { river, } \\
\text { Chinkwende } \\
\text { village, } \\
\text { Bvumbwe. }\end{array}$ \\
\hline Near by land use & $\begin{array}{l}\text { Smallholder } \\
\text { farmer's } \\
\text { maize field }\end{array}$ & $\begin{array}{l}\text { Smallholder } \\
\text { farmer's } \\
\text { tobacco field }\end{array}$ & $\begin{array}{c}\text { Herbicide } \\
\text { experimental } \\
\text { plot }\end{array}$ & $\begin{array}{l}\text { Tobacco } \\
\text { estate }\end{array}$ & $\begin{array}{l}\text { Smallholder } \\
\text { farmer's } \\
\text { maize field }\end{array}$ \\
\hline Topography & $\begin{array}{l}\text { Gentle } \\
\text { slope }\end{array}$ & Relatively flat & Gentle slope & Gentle slope & Gentle slope \\
\hline $\begin{array}{l}\text { Herbicides } \\
\text { applied }\end{array}$ & $\begin{array}{c}\text { Atrazine } \\
0.9 \mathrm{Kg} / \mathrm{Ha}\end{array}$ & $\begin{array}{l}\text { Metolachlor } \\
1.44 \mathrm{Kg} / \mathrm{Ha}\end{array}$ & $\begin{array}{l}\text { Atrazine and } \\
\text { Metolachlor }\end{array}$ & $\begin{array}{c}\text { Metolachlor } \\
1.44 \mathrm{Kg} / \mathrm{Ha}\end{array}$ & $\begin{array}{c}\text { Atrazine } \\
0.90 \mathrm{Kg} / \mathrm{Ha}\end{array}$ \\
\hline Field size & Large & Large & Very small & Very large & Large \\
\hline $\begin{array}{c}\text { Distance } \\
\text { between farm } \\
\text { and stream } \\
\end{array}$ & $\begin{array}{l}\text { About } \\
100 \mathrm{~m}\end{array}$ & About $10 \mathrm{~m}$ & About $60 \mathrm{~m}$ & $2 \mathrm{~m}$ & About $60 \mathrm{~m}$ \\
\hline Soil texture & $\begin{array}{l}\text { Sandy clay } \\
\text { loam }\end{array}$ & $\begin{array}{l}\text { Sandy clay } \\
\text { loam }\end{array}$ & Sandy loam & $\begin{array}{l}\text { Sandy clay } \\
\text { loam }\end{array}$ & $\begin{array}{l}\text { Sandy clay } \\
\text { loam }\end{array}$ \\
\hline $\begin{array}{l}\text { Intensity of rain } \\
\text { following } \\
\text { herbicide } \\
\text { application }\end{array}$ & Heavy & Light & Light & Moderate & Moderate \\
\hline
\end{tabular}

\section{3. Water analysis}

Atrazine and metolachlor in the unfiltered water sample was extracted with ethyl acetate, the extract was cleaned up with florisil then concentrated on a rotary evaporator. 


\section{3. 1. Water sample extraction with ethyl acetate}

The 1-litre water sample was saturated with $350 \mathrm{~g}$ of sodium chloride, divided into two $500 \mathrm{ml}$ portions and each portion transferred into a 1 litre separating funnel. To the $500 \mathrm{ml}$ aqueous solution were added $100 \mathrm{~g}$ of sodium chloride and shaken to dissolve then $120 \mathrm{ml}$ ethyl acetate were added. The funnel was shaken vigorously for 2 minutes, and the phases allowed to separate. The aqueous phase was drained into clean bottles, while the ethyl acetate phase was poured into a flask containing 15-20 g sodium chloride. The water phase was transferred from the bottle into the separating funnels. The bottles were rinsed with $60 \mathrm{ml}$ ethyl acetate and the washings poured into the separating funnel and extracted twice with ethyl acetate $(2 \times 60 \mathrm{ml})$.

The ethyl acetate extracts were collected in the same flask and transferred through a plug of glass wool into an E-flask containing $20 \mathrm{~g}$ of sodium sulphate. The E-flask was swirled and left to stand for 15 minutes until the drying agent flowed freely. If the drying agent solidified more sodium sulphate was added and swirling repeated until the sodium sulphate flowed freely.

The extract was decanted through a plug of glass wool into an evaporation flask, sodium sulphate rinsed with $20-30 \mathrm{ml}$ ethyl acetate and the washings decanted through the same glass wool plug, were combined with the original extract. The organic phase was cleaned up as shown below.

\section{3. 2. Clean up of extract with florisil}

The extract clean up method by Akerblom (1995) was used. A $10 \mathrm{~cm}$ long glass separating funnel was used as the clean up column. It was packed with $0.5 \mathrm{~cm}$ layer of glass wool, florisil adsorbent $(30 \mathrm{~g})$ and sodium sulphate $(5 \mathrm{~g})$. The column was washed with petroleum ether $(50 \mathrm{ml})$ and washings collected were discarded. Each sample extract (from 3.4.1.2, 3.4.1.3 and 3.4.1.4 above) was evaporated to dryness on a rotary evaporator at 400 ${ }^{\circ} \mathrm{C}$.

The residue was dissolved in $10 \mathrm{ml}$ petroleum ether, transferred into a petroleum ether conditioned column and allowed to penetrate the florisil. The pesticides were eluted with 200 $\mathrm{ml}$ of $7 \%$ diethyl ether in petroleum ether then $200 \mathrm{ml}$ of $25 \%$ diethyl ether. The pesticides in the extracts were concentrated as shown below.

\section{3. 3. Pesticide concentration}

Each eluate from the clean up column was concentrated by evaporation to about $2 \mathrm{ml}$ on a rotary evaporator, and the concentrated solution transferred to a graduated glass test tube placed in a water bath at $38{ }^{\circ} \mathrm{C}$, and further evaporated to about $0.4 \mathrm{ml}$ for thin layer chromatographic detection.

\section{3. 4. Pesticide detection}

Sample extracts and standards for atrazine and metolachlor solutions were run on the same chromatographic plate. Atrazine and metolachlor in the extracts were identified by the position of their spots (or retardation factors, Rf, calculated by dividing the distance travelled by herbicide with the distance travelled by solvent) and quantified by comparing the spots (size and intensity) of sample extracts against those of standard solutions (Akerblom, 1995). 
Dipping solution was prepared by dissolving $0.85 \mathrm{~g}$ silver nitrate in $5 \mathrm{ml}$ de-ionized water, adding $2.5 \mathrm{ml}$ concentrated ammonia solution and diluting to $200 \mathrm{ml}$ with acetone.

Readymade alumina plates were placed into the dipping solution for five seconds then withdrawn and allowed to dry in the fume hood. The dipped plates were stored in a dark place but used within a month.

The development chamber was lined with chromatographic paper. Ethyl acetate (Akerblom, 1995) was poured into the chamber to a level of $1.0-1.5 \mathrm{~cm}$ to moisten the paper. (This is done to saturate air in the development chamber with ethyl acetate vapour). Equal volumes $(0.05 \mathrm{ml})$ of sample extracts and reference standard solutions were applied as bands of equal size onto $20 \mathrm{~cm}$ alumina plate, $1.5 \mathrm{~cm}$ from the bottom edge, with at least $1 \mathrm{~cm}$ left towards the edge of the plate and between bands. The bottom edge of the plate was dipped into acetone in a dish, ensuring that the acetone level did not reach the bands applied.

Acetone was allowed to rise to about $1 \mathrm{~cm}$ above the bands to concentrate them. Then the plate was removed from the dish and acetone allowed to evaporate completely from the plate. The plate was then put in the development chamber and developed, up to $15 \mathrm{~cm}$ from the bands after which, it was taken out and the solvent front marked immediately. Then the plate was exposed to ultraviolet light (without filter) from a ULTRA-VIOLET torch at a distance of $11 \mathrm{~cm}$. After two minutes coloured spots were seen and traced.

\section{RESULTS AND DISCUSSION}

\section{1. Extent of atrazine and metolachlor contamination}

The percentage of surface water bodies contaminated by atrazine was higher than that contaminated by metolachlor. Atrazine was detected in thirty eight percent whilst metolachlor was detected in fifteen percent of the water samples.

This is in contrast to both the lower application rate of atrazine $(0.9 \mathrm{~kg} / \mathrm{ha}$ compared to $1.44 \mathrm{~kg} / \mathrm{ha}$ for metolachlor) and its lower water solubility $(0.033 \mathrm{~g} / 1$ compared to $0.53 \mathrm{~g} / \mathrm{l}$ for metolachlor) but probably consistent with soil and water conservation practices. Atrazine is largely used by smallholder maize farmers whereas metolachlor is mostly used by estate (commercial) tobacco farmers.

Table 2: Occurrence of herbicide residues in surface water samples ${ }^{1}$

\begin{tabular}{|c|c|c|c|c|c|c|c|c|c|}
\hline Herbicide & \multicolumn{3}{|c|}{$\begin{array}{c}\text { Atrazine (++++ for } 2 \mu \mathrm{g} / \mathbf{l} \\
\text { standard) }\end{array}$} & \multicolumn{3}{c|}{$\begin{array}{c}\text { Metolachlor (++++ for 10 } \\
\mu g / l \\
\text { standard) }\end{array}$} \\
\hline Site & & $\mathrm{A}$ & $\mathrm{B}$ & $\mathrm{B}_{1}$ & $\mathrm{C}$ & $\mathrm{A}$ & $\mathrm{B}$ & $\mathrm{B}_{1}$ & $\mathrm{C}$ \\
\hline Stream 1 & 1 & + & +++ & & ++ & - & - & & - \\
\hline & 2 & + & ++ & & ++ & - & - & & - \\
\hline & 3 & - & + & & + & - & - & & - \\
\hline
\end{tabular}




\begin{tabular}{|c|c|c|c|c|c|c|c|c|c|}
\hline & 4 & - & + & & - & - & - & & - \\
\hline \multirow[t]{4}{*}{ Stream 2} & 1 & & & - & & & & - & \\
\hline & 2 & & & - & & & & - & \\
\hline & 3 & & & - & & & & - & \\
\hline & 4 & & & - & & & & - & \\
\hline \multirow[t]{4}{*}{ Stream 3} & 1 & - & - & & - & - & - & & - \\
\hline & 2 & - & - & & - & - & - & & - \\
\hline & 3 & - & - & & - & - & - & & - \\
\hline & 4 & - & - & & - & - & - & & - \\
\hline \multirow[t]{4}{*}{ Stream 4} & 1 & & - & - & & & ++ & ++ & \\
\hline & 2 & & - & - & & & ++ & ++ & \\
\hline & 3 & & - & - & & & + & + & \\
\hline & 4 & & - & - & & & - & + & \\
\hline \multirow[t]{4}{*}{ Stream 5} & 1 & ++ & ++++ & & +++ & - & - & & - \\
\hline & 2 & + & +++ & & ++ & - & - & & - \\
\hline & 3 & + & ++ & & ++ & - & - & & - \\
\hline & 4 & + & + & & + & - & - & & - \\
\hline
\end{tabular}

${ }^{11}$ Key: $\mathbf{1}$ = sampled within first week of herbicide application, after first run off event; $\mathbf{2}=$ sampled between second and third weeks of herbicide application; $\mathbf{3}=$ sampled one month after herbicide application; $\mathbf{4}$ = sampled two months after herbicide application; - means no herbicide was detected and number of pluses indicates relative concentration of herbicide; $\mathbf{A}=$ upstream of herbicide application area; $\mathbf{B}$ or $\mathbf{B}_{1}=$ within the herbicide application area; $\mathbf{C}=$ downstream of herbicide application area; Blank means herbicide was not determined because either similar point was sampled (B or $\mathrm{B}_{1}$ ) or herbicide was not applied close to the that point of the river (stream 2).

The latter usually practice better land husbandly management practices than the former hence less export of metolachlor to surface water bodies due to less erosion of the soil. Some estate farmers maintained small percentages of their production areas as chemical (herbicide) filtering land. No atrazine and metolachlor were detected in groundwater from boreholes. 


\section{2. Trend in atrazine and metolachlor contamination}

The effect of time on herbicide levels in surface water is shown in Table 2. The number of pluses indicates relative intensity of the herbicide levels in the water. The results indicate that the relative concentration levels of atrazine were higher than those of metolachlor, probably due to the same soil and water conservation practices mentioned in 3.1 above. The highest herbicide concentrations in surface waters occurred following the first run off events and decreased with time; decreasing to zero at $37 \%$ of the contaminated sites by the eighth week and at all sites by the twelfth week. The decrease in concentration was probably due to decrease in soil concentrations, which led to lower run off concentrations. [When an herbicide is applied to the soil surface, the initial concentration at the surface immediately begins to diminish due to herbicidal action, microbial and chemical (including photochemical) degradation and volatilization (Guenzi, 1974; Cheng, 1990)].

The results showed that export of herbicides to surface water depends on adsorption and rate of pesticide application. When small quantities of herbicides were applied surface water contamination did not occur, as evidenced by Mponda River (stream 3). Traces of herbicides that may have run off were eventually adsorbed by the soil over which the water ran. Also the clay soil near stream 2 adsorbed herbicide residues, preventing contamination of the stream.

The results also showed that surface water contamination depends on upstream and in stream activities. For Chipanje river (stream 5) and stream 1 the upstream water samples had atrazine. This implied that some farmers upstream had applied atrazine on their crop fields.

The atrazine may have run off with rainwater from a sprayed land or drifted onto the riverine during herbicide spray elsewhere. According to Hitch et al (1995) spray drift can spread up to hundreds of kilometres. The lower downstream (point C) herbicide levels, for all streams, are possibly due to dilution (mixing of influent with water) and / or in-stream degradation, volatilization or uptake.

The distance between stream and herbicide treated soils also affected herbicide export to surface water. Stream 1 had less atrazine than stream 5 probably because it is further away from the maize field than stream 5. The larger distance meant relatively more chances of adsorption of the atrazine from the run off water by the soils over which the water ran. The extra land, which had grass, acted like a filtering area. According to Sun and Cornish (2003) filtering action is better if land is planted with grass.

The spots for standards for atrazine $(2 \mu \mathrm{g} / \mathrm{ml})$ and metolachlor $(10 \mu \mathrm{g} / \mathrm{ml})$ gave the highest number of pluses (four pluses). This means that herbicide concentrations in the concentrated water sample extracts were generally less than $2 \mu \mathrm{g} / \mathrm{l}$ atrazine or $10 \mu \mathrm{g} / \mathrm{l}$ metolachlor. The concentrated extracts were obtained from 1 litre of the water sample.

Therefore a concentration of $1 \mathrm{ug} / \mathrm{ml}$ in the concentrated extract means a concentration of $1 \mu \mathrm{g} / 1(\mathrm{ppb})$ in the water in the stream. This means herbicide concentrations in the streams were below the WHO allowed limits of $2 \mu \mathrm{g} / \mathrm{l}$ atrazine and $10 \mu \mathrm{g} / 1$ metolachlor (WHO, 2004). (Only for stream 5, following the first run off events, would the concentration of atrazine have equalled or slightly exceeded the WHO recommended limit). The atrazine levels for stream 5 are cause for concern.

There is need for proper quantification of herbicides in water using appropriate equipment. Currently, the central water laboratory which is responsible for water quality monitoring does not have a gas or liquid chromatograph. There is need for Government to invest in laboratory equipment and procure GC/MS or HPLC to be used in pesticide residue 
monitoring. To prevent export of herbicides to surface water farmers should establish vegetative filter strips.

These are narrow strips of permanent vegetation (usually grass) planted adjacent to cropland with the intent to reduce herbicide transport from agricultural application zones. Barfield et al (1998) has reported that vegetative filter strips increase the retention time of surface run off and thus reduce herbicide losses through facilitating the deposition of sediment-adsorbed compounds, enhancing herbicide retention by increasing time available for infiltration and sorbing dissolved-phase herbicides to the grass and soil surface.

\section{CONCLUSION}

No herbicide residue was detected in the groundwater samples. In surface water samples atrazine was detected in 38\% and metolachlor was detected in $15 \%$ of the samples.

The concentrations of the herbicides were at their highest soon after the first run off event after herbicide application. The concentrations, however were generally below the World Health Organization's (WHO's) recommended maximum guideline values.

Following the first run off event concentrations of herbicides steadily decreased with time, decreasing to zero within eight weeks of herbicide application at $37 \%$ of the water sampling points that had herbicide contamination. Light soaking rains, higher clay content, flat land, longer distance between agricultural land and surface water body (filtering area), lower herbicide application rates and herbicide incorporation seemed to reduce herbicide export to surface water.

\section{Recommendation}

Based on the study it is recommended that regular monitoring of pesticides in water should be done and that quantification of the pesticides should be done gas or liquid chromatograph with appropriate detectors. It is also recommended to follow good land husbandry practices to reduce export of pesticides to water bodies.

\section{References}

[1] Akerblom M., Environmental monitoring of pesticide residues. Guidelines for the SADC region. SADC ELMS, 1995.

[2] A. Ayanaba, W. Verstraete, M. Alexander, Proc. Am. Soil Sci. 37 (1973) 565-568.

[3] Banda L., A Study of the seasonal and spatial variations of chemical pollutants in Lunyangwa river basin, Mzuzu, Malawi. M. Sc. Thesis. Chancellor College, University of Malawi. Malawi, 2004.

[4] Chapman D., Water quality assessments, (UNESCO, WHO and UNEP), Chapman and Hall. New York and London 1992. 
[5] Cheng H. H., (Ed.). Pesticides in the soil environment: Processes, Impacts and Modelling. Soil Science Society of America Inc., Madison, WI., 1990.

[6] Du Preez L. H., Jansen Van Rensburg P. J., Jooste A. M., Carr J. A., Giesy J. P., Gross T. S., Kendall R. J., Smith E. E., Van Der Kraak G., Solomon K. R., Seasonal exposures to triazine and other pesticides in surface waters in the Western Highveld corn - production region in South Africa. Environ. Pollution 135(1) (2005) 131-141.

[7] EWG (Environmental working group). Weed killers by the glass, Fort Wayne, Indiana, 2004.

[8] http://www.ewg.org/pub home/Reports/weed-killer/Fort Wayne.html EXTOXNET Pesticide information profile Metolachlor, (Extension Toxicology Network). (2000a).

EXTOXNET Metolachlor (Dual) herbicide profile, 2/85. Extension Toxicology Network, 2000b.

[9] http://www.extoxnet.orst.edu

EXTOXNET Pesticide information profile Metolachlor, Extension Toxicology Network, 1996.

[10] Guenzi W. D., Pesticides in Soil and Water, Soil Science Society of America, Inc.: Madison, WI, (Ed.) 1974.

[11] Hayes T. B., Collins A., Lee M., Mondoza M., Noriega N., Stuart A. A., Vonk A., Hermaphroditic, demasculined frogs after exposure to the herbicide atrazine at low ecologically relevant doses. Proc. Nat. Acad. Sci. U S A 99 (2002) 5476-5480

[12] Hitch R. K., Akesson N. B., Jones A. W., Chapter 19: Intermediate range deposition of pesticides from arial applications, Lewis Publishers, 1995.

[13] Leng M. L. Leovy E. M. K., Zubkoff P. L., (Eds). Agrochemical environmental fate - state of the art. Lewis Publishers, 1995.

[14] Kamperewera A. M., Mbalame E., Banda A. M., Chilombe S., Hydrology, Water Quality Monitoring and Assessment, Malawi Environmental Monitoring Program (MEMP), Lilongwe, Malawi, 2000.

[15] Karrlson H., Muir D. G. D., Teixiera C. F., Buniston D. A., Hecky R. E., Strachan V. M. J., Gift N. P., Kidd K. A., Rosenberg B., Environ. Sci. Technol. 34 (2000) 4490-4495.

[16] Kearney P. C., Kaufman D. D., Herbicides chemistry, degradation and mode of action, ( $2^{\text {nd }}$ Ed.). Volume 1. Marcel Dekker Inc., 1975.

[17] Laabs V., Amelung W., Pinto A., Zech W., J. Environ. Qual. 31(1) (2002) 256-268.

[18] Lakudzala D. D., Sorption, degradation and movement of atrazine and metolachlor in some Malawi soils, $\mathrm{PhD}$ Thesis, University of Malawi, Zomba, Malawi, 2009.

[19] Lanchote V. L., Bonato P. S., Santos N. A., de Carvalho N. A., Gomes M. A., Water Air Soil Pollution 118 (2000) 329-337. 
[20] Larson R. A., Weber E. J., Reaction mechanisms in environmental organic chemistry, Lewis Publishers, Boca Raton, Ann Arbor, London, Tokyo 1994.

[21] Lengyel Z., Foldenyi, R., J. Soils and Sediments 2(3) (2002) 155-160.

[22] Li Q. X., Huang E. C., Guo F., Bull. Environ. Contam. Toxicol. 66 (2001) 653-659.

[23] McConnell L., Environmental and agricultural factors controlling pesticide volatilization, transport and deposition - Monitoring results, 2005.

http://www.epa.gov/oppefedl/models/water/mcconell-second_april_2005.htm

[24] MEREP. Malawi Economic Report on Environmental Policy. Office of the President and Cabinet, Government of Malawi, Lilongwe, 1995.

[25] Rebich R. A., Coupe R. H., Thurman E. M., J. Sci. total Environ. 321 (2004) 189-199.

[26] Saka J. K., Chemical pollution of Lake Chilwa. State of Lake Chilwa Environment Report No 16. Environmental Affairs Department, Lilongwe, Malawi, 1999.

[27] Savoca M. E., Eric M. Sadarf, S. Mike L., Kymm K. B. Akers., Effect of land use and hydrogeology on the water quality of alluvial aquifers in eastern Iowa and southern Minnesota. 1997 U.S, geological survey, Water Resources Investigations Report 99-4246. Iowa City, IA., 2000.

[28] Stockholm Convention. Stockholm Convention on Persistent Organic, Pollutants., Text and Annexes, Geneva, Switzerland, 2001. http://www.pops.int/

[29] Sun H., Cornish P. S., Management options to minimize atrazine and metolachlor export from grain cropping areas. Proceedings of the $11^{\text {th }}$ Australian Agronomy Conference, Geelung, 2003.

http://www.uws.edu.au

[30] US EPA (United States Environmental Protection Agency). Groundwater and Drinking water. Technical Fact sheet on Atrazine. Nov. 2002.

http://www.epa.gov/OGWDW/dwh/t-soc/atrazine.html

[31] USGS (United States Geological Surveys), Herbicide Fact sheet: Environmental contamination and ecological effects. J. Pesticide Reform 21(3), 2001.

http://www.pesticide.org/atrazineEnv.pdf

[32] GOM (Government of Malawi)., SG 2000 Malawi. Sasakawa African Association/Global 2000 Agricultural Programme in Africa. Lilongwe, Malawi, (2006).

[33] Van Leeuwen J. A., Waltner-Toews D., Abernathy T., Smith B., Shokri M., Int. J. Epidemiol. 28 (1999) 836-890.

[34] WHO (World Health Organization), Guidelines for drinking - water quality. ( $2^{\text {nd }}$ Ed.). Vol. 2, Health criteria and other supporting information. World Health Organization. Geneva, Switzerland, 1996, pages 725-729. 
[35] WHO (World Health Organization), Public Health Impact of pesticides used in agriculture. World Health Organization. Geneva, 1990.

[36] Zeljezic D., Garaj-Vrhovac V., Perkovic P., Toxicol. in Vitro 20(6) (2006) 923-935.

[37] Zweig G., Sherma J., Analytical methods for pesticides and plant growth regulators. Volume VI Gas Chromatographic Analysis. Academic Press Inc. New York and London, 1972. 